Article

\title{
Invasive Species Control: Predation on the Alien Crab Percnon gibbesi (H. Milne Edwards, 1853) (Malacostraca: Percnidae) by the Rock Goby, Gobius paganellus Linnaeus, 1758 (Actinopterygii: Gobiidae)
}

\author{
Francesco Tiralongo ${ }^{1,2, * \mathbb{D}}$, Giuseppina Messina ${ }^{1}$ and Bianca Maria Lombardo ${ }^{1}$ \\ 1 Department of Biological, Geological and Environmental Sciences, University of Catania, 95124 Catania, Italy; \\ giuseppina.messina@unict.it (G.M.); bm.lombardo@unict.it (B.M.L.) \\ 2 Ente Fauna Marina Mediterranea, 96012 Avola, Italy \\ * Correspondence: francesco.tiralongo@unict.it
}

\section{check for}

updates

Citation: Tiralongo, F.; Messina, G.; Lombardo, B.M. Invasive Species Control: Predation on the Alien Crab Percnon gibbesi (H. Milne Edwards, 1853) (Malacostraca: Percnidae) by the Rock Goby, Gobius paganellus Linnaeus, 1758 (Actinopterygii: Gobiidae). J. Mar. Sci. Eng. 2021, 9 , 393. https://doi.org/10.3390/ jmse 9040393

Academic Editor: Gualtiero Basilone

Received: 22 February 2021

Accepted: 2 April 2021

Published: 7 April 202

Publisher's Note: MDPI stays neutra with regard to jurisdictional claims in published maps and institutional affiliations.

Copyright: (c) 2021 by the authors. Licensee MDPI, Basel, Switzerland. This article is an open access article distributed under the terms and conditions of the Creative Commons Attribution (CC BY) license (https:/ / creativecommons.org/licenses/by/ $4.0 /)$.
Abstract: Invasive alien species (IAS) are one of the greatest causes of native species extinction. Indeed, they represent a global threat for biodiversity and can also affect the economy and human health. The colonization success of IAS is presumably not only due to their biological and ecological characteristics, but also to the lack of predators and/or parasites in the invaded new areas. In the present work, we demonstrate evidence of predation of the invasive alien crab Percnon gibbesi (H. Milne Edwards, 1853) by the Rock Goby Gobius paganellus Linnaeus, 1758. The diet of G. paganellus was studied analyzing the stomach content of 162 specimens collected in the central Mediterranean Sea. The results obtained from the calculation of the diet indices, namely, frequency of occurrence $(\% \mathrm{~F})$, percentage weight $(\% \mathrm{~W})$, percentage abundance $(\% \mathrm{~N})$, and the Index of Relative Importance (\%IRI), showed that small benthic crustaceans were the main prey types. Additionally, these indices and the Levins' index $(\mathrm{B} i)$ clearly indicated that the invasive crab P. gibbesi was by far the most abundant prey type in the diet of G. paganellus. The relevance of this predator-prey interaction and the role of native species for the biological control of invasive ones are discussed. We also provide a general view on the diet of G. paganellus and other biological and ecological aspects of specimens studied from the central Mediterranean Sea.

Keywords: Mediterranean Sea; invasive species; non-indigenous species; biological control; prey-predator interactions

\section{Introduction}

Non-indigenous species (NIS), and in particular invasive alien species (IAS), represent a serious threat to ecosystems' integrity, interfering with key ecological processes. Several studies have demonstrated that IAS can reduce the abundance and presence of native species through predation or competition and can alter food webs and community structure $[1,2]$. Indeed, they are considered to be the greatest cause of native species extinctions after habitat destruction [3]. In some cases, these alterations to the ecosystem can cause severe economic losses, sometimes exceeding those of natural disasters, and represent a threat to human health $[4,5]$. Although the dynamics of biological invasions are complex and often unclear, the results of several studies have suggested that areas with high species richness are more resistant to biological invasions than areas poor in species. In the former areas, the scarce availability of a free ecological niche represents an obstacle to the spread of IAS, reducing the possibility of settlement and/or expansion. This hypothesis is known as the "biotic resistance hypothesis" [6,7]. In this context, but also in general, the role of native predators can be relevant for the biological control of IAS. Indeed, in some cases, native species can have a high potential to exert predatory control on invasive ones [8]. Among these, coastal fish species can potentially play a key role in the predation of IAS. 
Gobies comprise more than 1900 species, and are the largest family (Gobiidae) of marine fishes $[9,10]$. In the Mediterranean Sea, this family includes 73 species, thus being the most diverse fish group of the region [11]. Despite this and their relevance for marine ecosystems, an increasing interest in gobies only started recently, with several published studies on their biology and ecology and the description of new species [12-18].

Gobius paganellus Linnaeus, 1758 is a medium-sized goby (Gobiidae), whose distribution extends from the Mediterranean and Black Sea to the eastern Atlantic (from Scotland to Senegal), including the Atlantic islands of the Azores, Madeira, and the Canaries [19]. Furthermore, it represents one of the few fish species that has performed an anti-Lessepsian migration, reaching the Red Sea through the Suez Canal [20]. The maximum reported total length (TL) is $14 \mathrm{~cm}$ for males and $14.3 \mathrm{~cm}$ for females [12], but common sizes range from about 8 to $12 \mathrm{~cm} \mathrm{TL}$, and no marked differences in size are present between sexes [12,21,22]. It is a shallow waters species generally common on rocky bottoms, often occurring in tidal pools [22,23]. Total length at first maturity was estimated at 5.2-11.4 cm TL, depending on the sex and location, a size that can be reached at $1-3$ years of age $[12,21,22,24,25]$. Crustaceans are the main prey types in the diet of G. paganellus $[12,21,24,26]$, and, depending on the size, area, and season, there is a variation in the dominance of the different species on which this goby feeds. Hence, G. paganellus is an opportunistic predator. However, among crustaceans, amphipods and isopods, followed by Caridea and Brachyura, were recorded to be the most common prey in the diet of the species $[12,21,24,26]$.

Percnon gibbesi (H. Milne Edwards, 1853), commonly known as the Nimble Spray Crab, is a medium-sized crab whose distribution extends from California to Chile in the Pacific Ocean, from North Carolina to Brazil in the Western Atlantic Ocean, and from the Azores to Angola in the Eastern Atlantic Ocean [27]. After its first record in 1999 in the Mediterranean Sea, P. gibbesi has undergone a rapid expansion in the whole basin [28,29]. By year 2000, the rapid spread of the species was recorded in Sicily [30]. The great colonization success of this crab was attributed to several factors, such as an increase of sea water temperatures, the absence of competitors, the availability of unoccupied ecological niches, and life history characteristics such as some aspects of its reproductive biology and long planktotrophic larval stage [31]. However, to the best of our knowledge, the predation of this species by a native species has never been demonstrated for the Mediterranean Sea, because P. gibbesi was never found in the stomach of any analyzed species and no predators were directly observed to prey on the crab (e.g., $[7,12,15,21])$. Yet, native species can prey on invasive ones, and, in some cases, contribute to controlling their populations [8,32-36]. Although several means of introduction have been hypothesized for $P$. gibbesi (i.e., aquarium release, larval drift through the Strait of Gibraltar, adult migration, ballast waters, ship hulls), the most likely appears to be the introduction through shipping $[29,37,38]$. This species was often found among boulders covered by algal mats or in which this covering was almost absent, in very shallow waters [29]. This habitat simultaneously provides protection from predators and food supply, represented by small algae and other small sessile organisms [30]. Percnon gibbesi has been considered mainly herbivorous (algae-eating), but some authors demonstrated its opportunistic feeding behavior [29,30]. Indeed, the species was observed to prey on hermit crabs and polychaetes, and analysis of stomach content revealed that gastropods and crustaceans can constitute a considerable part of its diet $[39,40]$. In order to avoid diurnal predators, $P$. gibbes $i$ is more active starting from the evening hours [31,40]. In Mediterranean waters, ovigerous females were observed between May and September. Sexual dimorphism is present, with males showing chela length with a larger positive allometry than that of females [31]. According to some authors, P. gibbesi is a potential competitor of Pachygrapsus marmoratus (J.C. Fabricius, 1787), both for space and food resources, and a similar situation could be present with Eriphia verrucosa (Forskål, 1775), although both native crabs usually prefer inhabiting the rocky intertidal and very shallow waters, among crevices and holes or under boulders [31].

In the present study, we provide the first direct evidence of substantial predation of a native species, G. paganellus, on the invasive alien crab, P. gibbesi, emphasizing the role of 
the goby in the biological control of this invasive species. Furthermore, we also provide the first recorded data on some aspects of the biology and ecology of G. paganellus from the Ionian Sea (central Mediterranean Sea): length-weight relationship, total length-standard length relationship, size frequency distribution, diet, and feeding habits. For these latter two points, we analyzed and discussed the prey selectivity of the species.

\section{Materials and Methods}

A total of 162 specimens of G. paganellus were collected in the Ionian Sea (south-east coast of Sicily, central Mediterranean Sea), in an area between the localities of Avola and Noto, along a coastline extending for about $2 \mathrm{~km}$ (Figure 1). In order to better represent the investigated population, two collection areas were selected, that of Noto represented by a small semi natural harbor ( $36.86994 \mathrm{~N}, 15.13738 \mathrm{E}$ ) with rocky bottom and boulders and that of Avola represented by a natural rocky bottom area (36.88628 N, 15.14041 E). These areas were distant from each other by about $2 \mathrm{~km}$ and had a depth range of 0.1-1.5 $\mathrm{m}$. Sampling was performed during daytime with calm sea conditions, between 4 September and 5 December 2020. In this period, a total of 12 samplings were carried out, with an average of 13.5 specimens per sampling day (Table 1 ).

The specimens were caught with a fishing rod, using as bait fresh pieces of the Deepwater Rose Shrimp, Parapenaeus longirostris (H. Lucas, 1846). Specimens were killed in ice water immediately after their capture. Subsequently, each specimen was weighed and measured (total length and standard length). Total length and weight measures were used for the length-weight relationship following the formula: $\mathrm{W}=\mathrm{aTL}{ }^{\mathrm{b}}$, where $\mathrm{W}$ is the weight in grams $(\mathrm{g}), \mathrm{TL}$ is the total length in centimetres $(\mathrm{cm})$, $a$ is the intercept, and $\mathrm{b}$ is the slope of the regression curve; when $b=3$, the increase in weight is isometric; contrariwise, when the value of $b$ is different to 3 , the weight increase is allometric. In this latter case, if $b>$ 3 , the weight increase is positive allometric, and if $b<3$, the weight increase is negative allometric. A one-sample t-test was used to verify the null hypothesis of the isometric growth $\left(\mathrm{H}_{0}: \mathrm{b}=3\right)$. Length-weight relationships are valuable measurements in order to evaluate and compare the health conditions of species' population [41,42]. Total length (TL) and standard length (SL) measures were used for the total length-standard length relationship following the formula: $\mathrm{TL}=\alpha \mathrm{SL}+\beta$, where $\alpha$ is the slope and $\beta$ is the intercept of the regression line.

Table 1. Means of the basic measurements per sampling day for Gobius paganellus; $\mathrm{N}=$ total number of specimens; $\mathrm{N}$ Avola = specimens collected at Avola; N Noto = specimens collected at Noto; N Prey = specimens with at least one prey in their stomach; $\mathrm{TL}=$ total length; $\mathrm{SL}=$ standard length; $\mathrm{W}=$ weight.

\begin{tabular}{|c|c|c|c|c|c|c|c|}
\hline Date & $\mathbf{N}$ & N Avola & N Noto & N Prey & TL (cm) & SL (cm) & W (g) \\
\hline 4 September 2020 & 15 & 5 & 10 & 11 & 9.52 & 7.89 & 11.45 \\
\hline 14 September 2020 & 11 & 2 & 9 & 7 & 9.24 & 7.68 & 10.52 \\
\hline 21 September 2020 & 12 & 4 & 8 & 9 & 9.54 & 8 & 11.26 \\
\hline 28 September 2020 & 16 & 8 & 8 & 12 & 9.50 & 7.99 & 11.78 \\
\hline 2 October 2020 & 12 & 5 & 7 & 10 & 9.82 & 8.20 & 12.91 \\
\hline 9 October 2020 & 15 & 10 & 5 & 13 & 9.83 & 8.25 & 12.09 \\
\hline 16 October 2020 & 13 & 3 & 10 & 9 & 9.09 & 7.57 & 10.05 \\
\hline 27 October 2020 & 14 & 6 & 8 & 6 & 9.56 & 7.96 & 11.80 \\
\hline 3 November 2020 & 12 & 8 & 4 & 8 & 9.59 & 8.06 & 11.48 \\
\hline 10 November 2020 & 15 & 8 & 7 & 10 & 9.19 & 7.71 & 10.69 \\
\hline 22 November 2020 & 14 & 9 & 5 & 11 & 9.8 & 8.19 & 12.85 \\
\hline 5 December 2020 & 13 & 4 & 9 & 9 & 9.49 & 7.95 & 11.26 \\
\hline
\end{tabular}




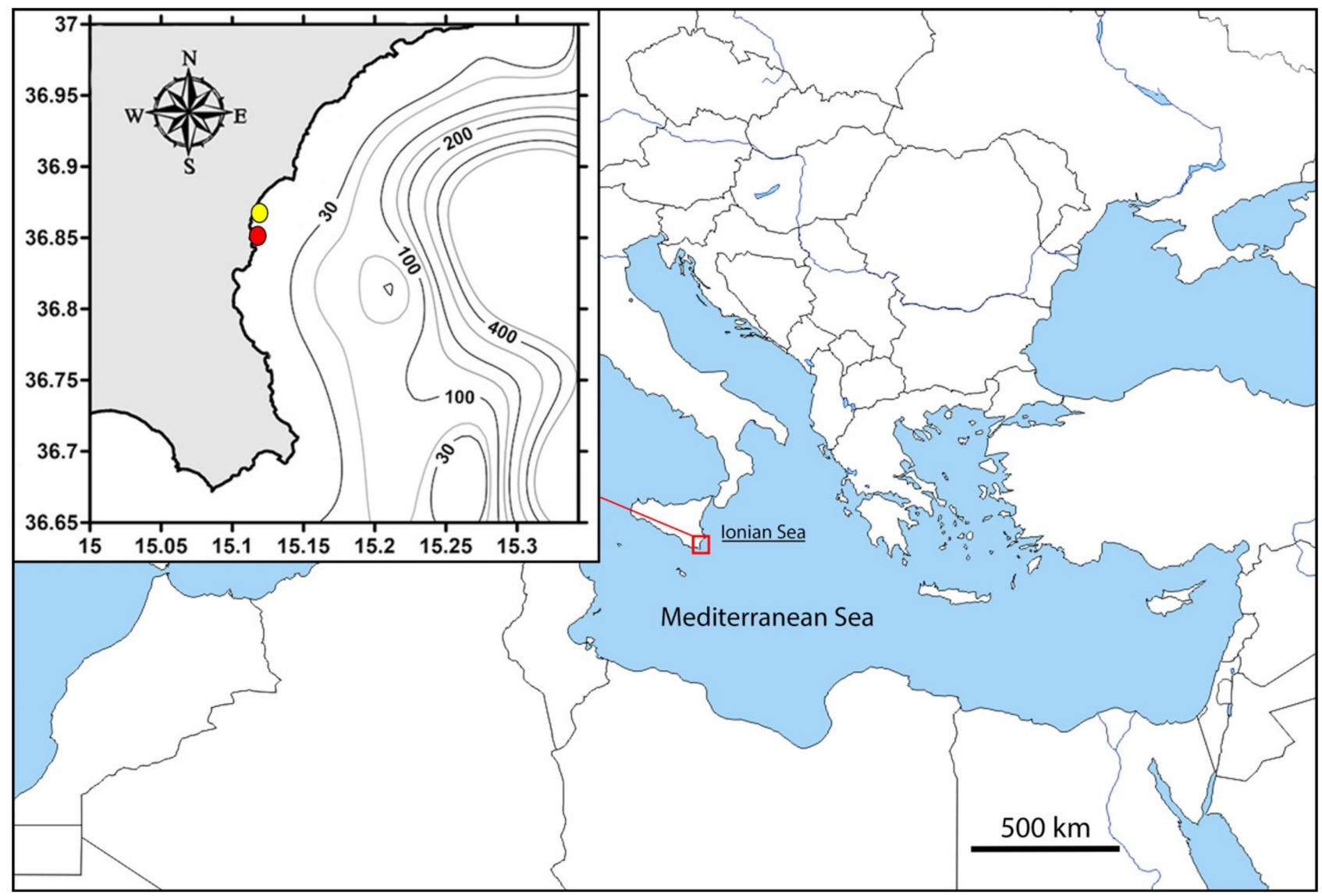

Figure 1. Study areas of Noto (in red) and Avola (in yellow) in the Ionian coast of Sicily (central Mediterranean Sea).

After measurements, the stomach was removed and the content analyzed under a stereoscopic microscope. All the prey items found were counted, washed in clean seawater and dried with blotter paper, identified to the lowest taxonomic level possible using identification manuals $[43,44]$, and weighed to the nearest $0.001 \mathrm{~g}$. After examination, stomach contents and gobies were preserved in ethanol.

The frequency of occurrence- $\% \mathrm{~F}$ (defined as the number of stomachs in which each specific prey type is represented expressed as percentage), percentage weight- $\% \mathrm{~W}$ (defined as the weight of each prey type in the stomachs examined expressed as percentage), percentage abundance- $\% \mathrm{~N}$ (defined as the number of individuals of each prey type in the stomachs examined expressed as percentage), and the Index of Relative Importance$\%$ IRI (calculated by summing $\% \mathrm{~N}$ and $\% \mathrm{~W}$ values and multiplying with $\% \mathrm{~F}$ value) were calculated for each taxon [45,46]. The percentage of empty stomachs (vacuity index)$\mathrm{V} \%$ (number of empty stomachs/total number of stomachs examined) $\times 100$, was also calculated.

Prey were grouped into three categories on the basis of their percentage abundance $(\% \mathrm{~N})$ [47]: dominant $(\mathrm{N}>50 \%)$, secondary $(10 \%<\mathrm{N}<50 \%)$, and accidental $(\mathrm{N}<10 \%)$.

Standardized Levins' index $(\mathrm{B} i)$ was used to evaluate the breadth of the diet [48]:

$$
\begin{gathered}
\mathrm{B}=\frac{1}{\sum p_{j}^{2}} \\
\mathrm{~B} i=\frac{\mathrm{B}-1}{\mathrm{~B}_{\max }-1}
\end{gathered}
$$

where $p_{j}$ is the relative frequency specimens in the jth prey item and $\mathrm{B}_{\max }$ is the total number of prey item categories found. $B i$ is comprised between 0 and 1 . The higher the value of this index, the wider the trophic niche of the species will be. Hence, if $B i<0.40$, the 
species is considered a "specialist feeder", if $0.40<\mathrm{Bi}<0.60$ the species is considered an "intermediate feeder", and if $\mathrm{B} i>0.60$, the species is considered a "generalist feeder" [49].

A cumulative prey curve [50] was computed with R Studio [51] using the "vegan" package in order to evaluate whether the number of analyzed stomachs was sufficient to describe the diet of the species. The estimated number of prey groups with the associated SD were plotted against the cumulative number of individuals whose stomach was examined.

\section{Results}

One hundred and fifteen out of a total of 162 specimens examined of G. paganellus had prey in their stomachs; thus, the vacuity index (percentage of empty stomachs) was $\mathrm{V} \%=29.01$. The cumulative prey curve approached an asymptote, suggesting that the analysis of about 100 not empty stomachs provides a reliable description of the diet of the goby (Figure 2). Analysis of stomach contents of G. paganellus included 20 prey types. Data showed that G. paganellus feed mainly on small benthic crustaceans (Table 2). In particular, values of $\% \mathrm{~F}, \% \mathrm{~W}, \% \mathrm{~N}$, and $\% \mathrm{IRI}$ indicated that $P$. gibbesi, which accounted for about one third of all prey items, was by far the most abundant prey type. This was also strongly supported by the Levins' index value $(\mathrm{B} i=0.39)$, indicating a narrow trophic niche ("specialist feeder"). The carapace width (CW) of the specimens of $P$. gibbesi found in the stomachs was about or less than $1 \mathrm{~cm}$. On a total of 20 prey types recorded, no "dominant" $(\mathrm{N}>50 \%)$ prey types were found, and the only "secondary" prey type $(10 \%<\mathrm{N}<50 \%)$ was represented by $P$. gibbesi. Hence, except for $P$. gibbesi, all the prey types fall into the category "accidental preys" ( $\mathrm{N}<$ $10 \%$ ) (Table 2). However, among these latter preys, the most represented were some Brachyura (Pisidia sp., Xantho sp., and juvenile specimens of P. marmoratus) and the hermit crab Clibanarius erythropus (Latreille, 1818). Eriphia verrucosa was the less represented crab $(\% \mathrm{~F}=4.35)$. The other groups of crustaceans found in the stomachs of the Rock Goby were Amphipoda, Caridea, and Isopoda. These latter groups of crustaceans and Algae showed similar values in diet indices (e.g., $\% \mathrm{~F}=6.09-6.96)$. Mollusca (gastropods) were overall less represented $(\% \mathrm{~F}=0.87-1.74$, excluding value for not identified Gastropoda), followed by Polychaeta and Seagrass $(\% \mathrm{~F}=2.61$ and 0.87 , respectively) (Table 2 ).

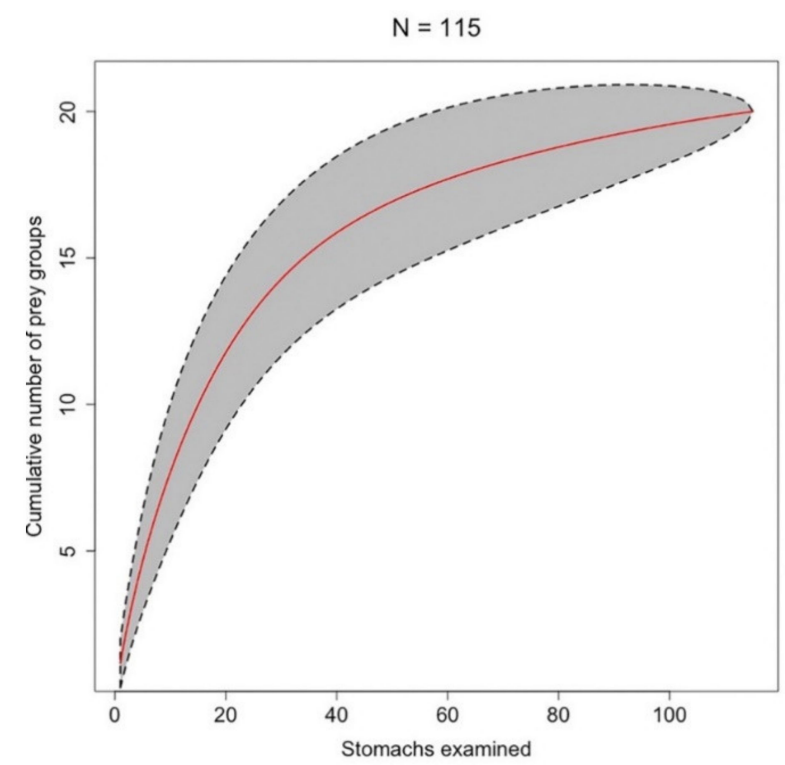

Figure 2. Cumulative prey curve (in red) as a function of sample size for all stomachs analyzed of Gobius paganellus. Standard deviation (SD) in grey delimited by dashed black lines. 
Table 2. Diet composition of G. paganellus $(\mathrm{N}=115)$ from the Ionian Sea (central Mediterranean Sea). \%F = percentage frequency of occurrence; $\% \mathrm{~N}=$ percentage in number; $\% \mathrm{~W}=$ percentage in biomass; IRI = index of relative importance of prey items and its percentage (\%IRI). Results for Percnon gibbesi are underlined.

\begin{tabular}{|c|c|c|c|c|c|}
\hline Prey types & $\% \mathrm{~F}$ & $\% \mathbf{N}$ & $\% W$ & IRI & \%IRI \\
\hline Mollusca & 11.31 & 9.36 & 10.24 & 49.916 & 1.62 \\
\hline Aplysia sp. & 0.87 & 0.72 & 1.63 & 2.0435 & 0.07 \\
\hline Bittium lacteum & 0.87 & 0.72 & 0.54 & 1.0956 & 0.04 \\
\hline Patella caerulea & 1.74 & 1.44 & 1.01 & 4.2610 & 0.14 \\
\hline Tritia cuvierii & 1.74 & 1.44 & 1.90 & 5.8116 & 0.19 \\
\hline Gastropoda n.i. & 4.35 & 3.60 & 3.67 & 31.6087 & 1.02 \\
\hline Trochidae n.i. & 1.74 & 1.44 & 1.49 & 5.0956 & 0.16 \\
\hline Polychaeta & 2.61 & 2.16 & 0.95 & 8.113 & 0.26 \\
\hline Polychaetes n.i. & 2.61 & 2.16 & 0.95 & 8.113 & 0.26 \\
\hline Crustacea & 89.59 & 77.73 & 79.65 & 2925.5660 & 94.42 \\
\hline $\begin{array}{l}\text { Clibanarius } \\
\text { erythropus }\end{array}$ & 6.96 & 6.47 & 4.27 & 74.7130 & 2.41 \\
\hline Eriphia verrucosa & 4.35 & 3.60 & 3.49 & 30.8415 & 1.00 \\
\hline $\begin{array}{c}\text { Pachygrapsus } \\
\text { marmoratus }\end{array}$ & 5.22 & 5.04 & 5.03 & 52.5391 & 1.70 \\
\hline Percnon gibbesi & $\underline{33.91}$ & 30.22 & $\underline{40.15}$ & $\underline{2386.4608}$ & 77.01 \\
\hline Pisidia sp. & 6.09 & 5.04 & $\overline{12.42}$ & 106.2782 & 3.43 \\
\hline Xantho sp. & 6.96 & 5.76 & 4.17 & 69.0783 & 2.23 \\
\hline Amphipoda n.i. & 6.09 & 5.04 & 1.22 & 38.1234 & 1.23 \\
\hline Brachyura n.i. & 6.96 & 5.76 & 4.61 & 69.3753 & 2.24 \\
\hline Caridea n.i. & 6.96 & 5.76 & 1.49 & 50.4347 & 1.63 \\
\hline Isopoda n.i. & 6.09 & 5.04 & 2.80 & 47.7217 & 1.54 \\
\hline Algae & 6.09 & 5.04 & 3.53 & 52.1652 & 1.68 \\
\hline $\begin{array}{c}\text { Seagrass (Posidonia } \\
\text { oceanica) }\end{array}$ & 0.87 & 0.72 & 0.43 & 1.0005 & 0.03 \\
\hline Digested & 6.09 & 5.04 & 5.19 & 62.2695 & 2.01 \\
\hline
\end{tabular}

In the specimens sampled in the small semi natural harbor $(\mathrm{N}=90), P$. gibbesi was found in $43.3 \%(\mathrm{~N}=39)$ of the stomachs. In contrast, $P$. gibbesi was absent from the stomach contents of specimens sampled in the nearby natural rocky bottom area. In the whole sample of G. paganellus with at least one prey in their stomach $(\mathrm{N}=115), P$. gibbesi was found in $33.9 \%$ of the stomachs analyzed. However, in order to compare the diet of the goby in the aforementioned locations, removing P. gibbesi from the analysis did not find any significant differences between them. In all cases, crabs and hermit crabs represented the most common prey types of the species, although no clear dominance was evident for any prey type (with the exception of $P$. gibbesi).

The size frequency distribution of the sampled specimens $(\mathrm{N}=162)$ showed a size range of 7.1-11.6 cm TL, with a mean of $9.5 \mathrm{~cm}$ (Table 3). The size frequency distribution was multimodal (Figure 3). The total length-weight relationship showed an isometric growth $(b=2.959 ; p$-value $>0.05)$ (Table 3$)$, while the parameters of the linear regression of total length-standard length relationship were: $\mathrm{TL}=1.136 \mathrm{SL}+0.4822$ (Figure 4). Means of the basic measurements per sampling day are reported in Table 1. 
Table 3. Total length, standard length, weight, and total length-weight relationship parameters of G. paganellus in the Ionian Sea (central Mediterranean Sea); $a=$ intercept of the regression curve; $b=$ slope; $r^{2}=$ coefficient of correlation; C.I. $=95 \%$ confidence interval.

\begin{tabular}{|c|c|c|c|c|c|c|c|c|}
\hline \multicolumn{3}{|c|}{ Total Length (TL)-cm } & \multicolumn{3}{|c|}{ Standard Length (SL)-cm } & \multicolumn{3}{|c|}{ Weight (W)-g } \\
\hline Range & Mean & SD & Range & Mean & SD & Range & Mean & SD \\
\hline $7.1-11.6$ & 9.5 & 1.11 & $5.9-9.6$ & 7.9 & 0.97 & $4.98-20.14$ & 11.53 & 3.80 \\
\hline $\mathbf{a}$ & \multicolumn{2}{|c|}{ C.I. a } & $\mathbf{b}$ & \multicolumn{2}{|c|}{ C.I. $b$} & $\mathbf{r}^{2}$ & \multicolumn{2}{|c|}{$p$-value } \\
\hline 0.014 & \multicolumn{2}{|c|}{$0.011-0.018$} & 2.959 & \multicolumn{2}{|c|}{$2.849-3.068$} & 0.95 & \multicolumn{2}{|c|}{$>0.05$} \\
\hline
\end{tabular}

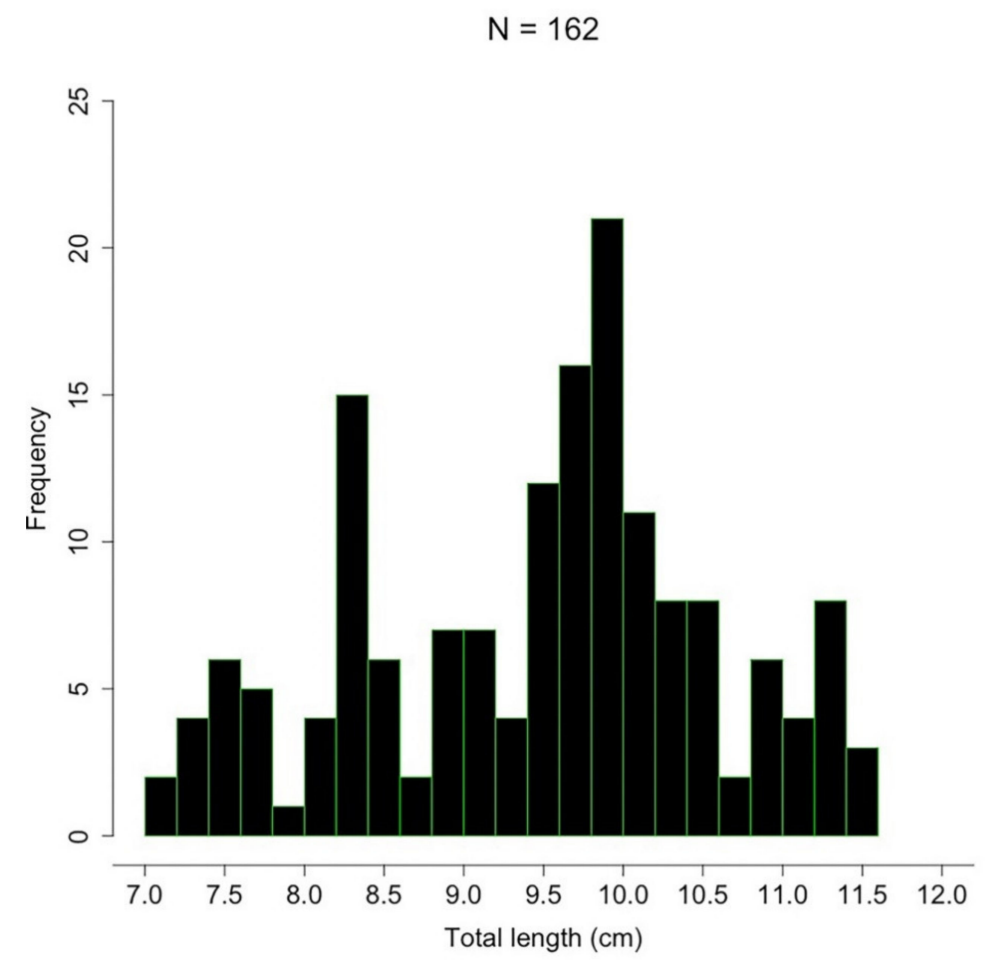

Figure 3. Size distribution (TL in $\mathrm{cm}$ ) of sampled specimens of G. paganellus.

A

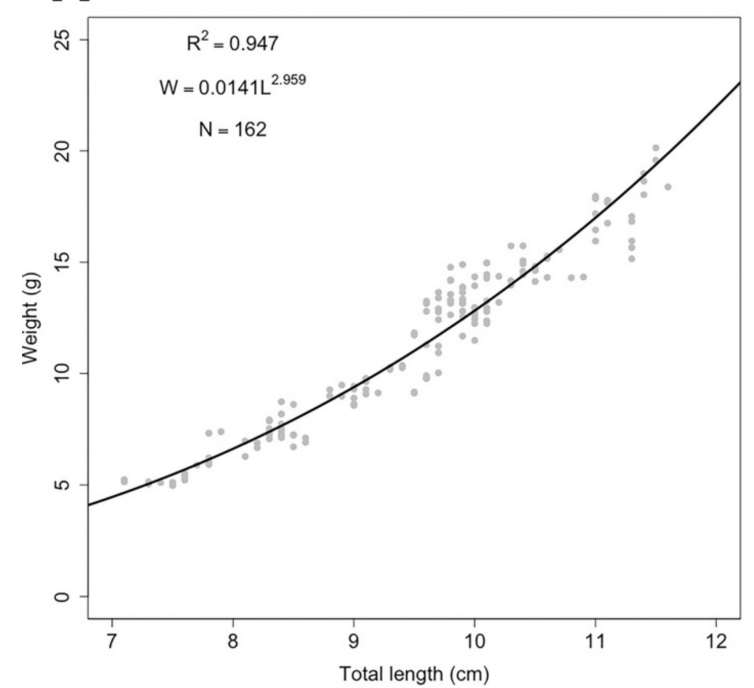

B

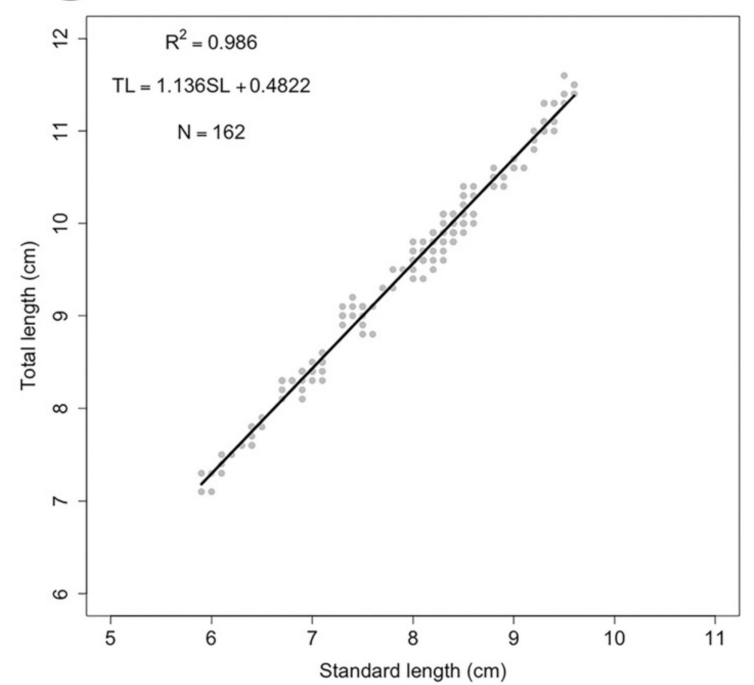

Figure 4. Total length-weight relationship (A) and total length-standard length relationship (B) of G. paganellus. 


\section{Discussion}

The diet analysis of G. paganellus clearly showed the dominance of the alien crab P. gibbesi. Indeed, this species of crab was found in the stomach of a considerable percentage of specimens $(\% \mathrm{~F}=33.91 ; \% \mathrm{IRI}=77.01)$. Considering the small size of the crabs found in the stomachs, they were all juveniles. A noteworthy fact is that $P$. gibbesi was found only in the stomach of specimens sampled in the small harbor $(\mathrm{N}=90)$. This can be explained by the fact that gobies are usually generalists and opportunistic feeders that take advantage of the most available prey. Furthermore, the gobies' diet was found to be often dependent on area and season $[14,15,52]$. Based on this, the relative abundance of alien crabs found in the stomach of specimens sampled in the small harbor can be the direct result of the different abundance of $P$. gibbesi in the two areas investigated, and point out the preference of the invasive crab for areas characterized by the presence of breakwaters and/or boulders. Indeed, some authors demonstrated the preference of the invasive crab for harbor's breakwaters, where diversity levels are generally low and where it can find a suitable habitat among breakwaters and boulders [39]. However, from our data, it was not possible to determine whether the goby selectively preys on the crab, or if the abundance of $P$. gibbesi found in the stomachs of G. paganellus was related to the greater presence of P. gibbesi in the waters of the small harbor.

In all cases, despite the relatively high value of the frequency of occurrence obtained for P. gibbesi, the overall diet of G. paganellus included a quite wide variety of benthic invertebrates, mainly consisting of small benthic crustaceans. Hence, the Rock Goby may be generally considered as an opportunistic carnivorous species. In other words, the narrow trophic niche indicated by the Levins' index is the result of the abundance of $P$. gibbesi in the stomachs of specimens of G. paganellus from the small semi natural harbor, otherwise G. paganellus can be considered as a "generalist feeder", as usually reported in literature. After P. gibbesi, other crab species, such as Pisidia sp., Xantho sp., and P. marmoratus (juveniles) and the hermit crab C. erythropus represent the most important prey types of G. paganellus. On the other hand, juveniles of E. verrucosa were less represented. Other relatively well represented groups of crustaceans were Amphipoda, Caridea, and Isopoda. Gastropods and polychaetes were rarely found. Finally, algae and seagrasses were probably accidentally ingested, as suggested by some authors for algae [24]. Our results are in general agreement with those reported in literature $[12,21,24,26]$ that describe the diet of G. paganellus as mainly composed of small benthic crustaceans, although with some differences among the crustacean groups recorded.

Considering the size range of the analyzed specimens, all the studied individuals of G. paganellus were of medium and large size. Indeed, no individual smaller than $7.1 \mathrm{~cm} \mathrm{TL}$ was recorded. The total length-weight relationship showed an isometric growth, while a positive allometric growth was recorded in specimens from a coastal lagoon of Spain [53]. The analysis of the total length-standard length relationship demonstrated that the SL is on average $83.16 \%$ of the TL.

Our study demonstrates for the first time how a native fish species can effectively prey on this invasive crab, reducing the abundance of the established population. Although $P$. gibbesi is quite elusive, G. paganellus, a strictly benthic goby of rocky and mixed bottoms, is able to predate on it among rocks and boulders, especially in areas in which the crab is particularly abundant and probably other resources are scarce. Further studies on a large spatio-temporal scale and on the ecology and mechanisms of predation and prey selection are necessary to better understand the role that can have predators such as G. paganellus and other native intertidal and shallow waters fish species on the Mediterranean population of P. gibbesi. Furthermore, considering the sizes of the preys found and the mouth opening of G. paganellus, a medium sized species of goby, the species is able to prey only on juvenile specimens of the crab, while species of larger size and with a wider mouth opening (e.g., Gobius cobitis, Muraena helena, Scorpaena maderensis, Scorpaena porcus, Serranus cabrilla, Serranus scriba) should be investigated for their ability to feed also on adult specimens of P. gibbesi. In this regard, it is interesting to note how Sciberras and Schembri [31] reported 
that in the nearby Maltese waters, the juveniles of $P$. gibbesi were observed between the end of September until at least March, a period that overlaps with that of our study. This would suggest how in Sicily the recruitment could also occur in this period and probably extend for a similar period too. Further studies mentioned above could also clarify this point. To further confirm what was also reported by the same authors, namely the habitat overlap between P. gibbesi and P. marmoratus in particular, but also with E. verrucosa, we also found these two latter species in the stomach content of G. paganellus, and P. marmoratus was more common than E. verrucosa. Another interesting aspect concerning the native predators' control of the population of the invasive $P$. gibbesi was recently pointed out by Noè et al., 2018 [7]. Results obtained by the authors suggested how in areas with high diversity and an abundance of potential predators (e.g., marine protected areas) of P. gibbesi, the abundance of the invasive crab is generally lower than in non-protected areas where potential predators are scarcely represented. Other studies are needed in order to clarify the relationships and dynamics between $P$. gibbesi and the presence and abundance of its actual predators.

Invasive species can alter marine ecosystems and cause biodiversity loss, economic damages affecting areas such as fisheries, tourism, and recreational activities, and a threat to human health. Especially in marine environments, totally eradicating or stopping the spread of an invasive alien species have never been successful, and the only valid alternative to date is to limit the spread and abundance through targeted actions [3-5]. For some palatable or even edible alien species, direct actions such as fisheries for human consumption can be a valid solution in order to reduce population. In contrast, when we face non-edible invasive species such as the case of $P$. gibbesi, the promotion and protection of natural predators of invasive species, and the general promotion of the "biotic resistance" (that is, the ability of native species in a community to limit and control the invasion of other species), can be valid additional resources in order to control invasive populations of alien species $[7,54,55]$. Several studies have already shown how some native species prey on non-indigenous ones, and, in some cases, they are capable of effectively controlling their populations [8,34-36]. Although further studies are necessary in order to better understand this and other predator (native)-prey (IAS) interactions, G. paganellus seems to perform the function of "autoregulator" of $P$. gibbesi abundance. Indeed, considering the opportunistic and generalist feeding behavior of G. paganellus (and of gobies in general), it preys on the crab especially when the latter is very abundant.

Invasive species can replace or limit the abundance of native ones, alter the habitat structure, and interfere with biogeochemical processes [8,56]. As mentioned above, in a marine environment, the eradication of IAS is complicated, and no eradication attempts have so far been successful. Hence, prevention methods should be prioritized over those of eradication. In this regard, the "biotic resistance" provided by a well-structured native community can act as a natural barrier in preventing or slowing biological invasions. Indeed, on the basis of the mechanisms of competition, IAS cannot establish in a niche similar to that of native species [57]. Furthermore, the occupation of niches is more complete in a species-rich and well-structured native community, and this further contributes to preventing biological invasions [58]. In this regard, the role of native predators, such as in the case here presented of G. paganellus, can effectively contribute to controlling populations of invasive species [8]. Although we have no data to state if some specimens of the Rock Goby can learn to prey selectively on the invasive crab, they can certainly contribute to reducing their number. Furthermore, the discovery of the existence of a combination of native predators of the crab would show how, overall and at least in some locations, they could significantly contribute to controlling and limiting the population's growth of the invasive crab. Particular measures could also be promoted in order to protect the population of key native species from human activities. 


\section{Conclusions}

In conclusion, our study demonstrates how the native fish G. paganellus can prey on the invasive crab P. gibbesi, being able to contribute to the control of the population of this IAS in the Mediterranean Sea. Although P. gibbesi was the dominant prey type, the diet of G. paganellus was composed of a wide variety of invertebrates, mainly represented by small benthic crustaceans, brachyurans in particular. Hence, we can consider this species as an opportunistic feeder able to prey on $P$. gibbesi too, thus potentially playing a role in the biological control of the species. However, more studies are needed to understand if the native goby can (and under what conditions) develop the ability to selectively feed on P. gibbesi. Furthermore, other studies can help to expand this research to other species and areas in order to evaluate the overall impact of predation of the coastal fish community on this invasive crab (and other invasive species), and relate the presence of the major predators of $P$. gibbesi to its abundance levels at several locations. This study also provided the first biological and ecological data on G. paganellus from specimens from the Ionian Sea (central Mediterranean Sea).

The lack of predators and/or parasites can cause overpopulation of invasive species in their new colonized areas, especially if these species cannot be exploited economically by fishery because they have no economic value. Percnon gibbesi falls in this latter category and showed a great success in colonizing the Mediterranean Sea, with potentially negative although unpredictable effects on the ecosystem.

To date, no studies had shown a direct predation on this crab by a native species. Although our study clearly demonstrated the predation of the native G. paganellus on the invasive crab P. gibbesi, further studies are still needed in order to better understand the mechanisms of this predator-prey interaction, the degree of contribution that this predation can have in controlling the abundance of this invasive species, and if other Mediterranean populations of the goby have adapted or are able to prey on this invasive crab. Furthermore, it is very likely that other species as well, such as some coastal fish, prey on P. gibbesi, and other studies should focus on finding out which ones and to what extent they can contribute overall to the control of the invasive Mediterranean population of the crab.

Author Contributions: Conceptualization: F.T.; methodology: F.T., G.M. and B.M.L.; investigation: F.T. and G.M., formal analysis: F.T., G.M. and B.M.L.; writing-original draft preparation: F.T. and G.M.; writing - review and editing: F.T., G.M. and B.M.L. All authors have read and agreed to the published version of the manuscript.

Funding: This research received no external funding.

Institutional Review Board Statement: Ethical review and approval are not necessary for this study because collected specimens come from fishing activities and have been treated ethically.

Informed Consent Statement: Not applicable.

Data Availability Statement: Data will be made available on request.

Acknowledgments: Authors are grateful to Giacomo Bernardi, Department of Ecology and Evolutionary Biology, University of California Santa Cruz, for the English language review, and to the three anonymous reviewers for their helpful comments.

Conflicts of Interest: The authors declare no conflict of interest.

\section{References}

1. Ghosholz, E. Ecological and evolutionary consequences of coastal invasions. Trends Ecol. Evol. 2002, 17, 22-27. [CrossRef]

2. Molnar, J.L.; Gamboa, R.L.; Revenga, C.; Spalding, M.D. Assessing the global threat of invasive species to marine biodiversity. Front. Ecol. Environ. 2008, 6, 485-492. [CrossRef]

3. Bellard, C.; Cassey, P.; Blackburn, T.M. Alien species as a driver of recent extinctions. Biol. Lett. 2016, 12, 20150623. [CrossRef]

4. Ricciardi, A.; Palmer, M.E.; Yan, N.D. Should biological invasions be managed as natural disasters? BioScience 2011, 61, 312-317. [CrossRef] 
5. Bailey, S.; Brown, L.; Campbell, M.; Canning-Clode, J.; Carlton, J.; Castro, N.; Chainho, P.; Chan, F.T.; Creed, J.C.; Curd, A.; et al. Trends in the detection of aquatic non-indigenous species across global marine, estuarine and freshwater ecosystems: A 50-year perspective. Divers. Distrib. 2020, 26, 1780-1797. [CrossRef]

6. Hooper, D.U.; Chapin, F.S.; Ewel, J.J.; Hector, A.; Inchausti, P.; Lavorel, S.; Lawton, J.H.; Lodge, D.M.; Loreau, M.; Naeem, S.; et al. Effects of biodiversity on ecosystem functioning: A consensus of current knowledge. Ecol. Monogr. 2005, 75, 3-35. [CrossRef]

7. Noè, S.; Gianguzza, P.; di Trapani, F.; Badalamenti, F.; Vizzini, S.; Fernández, T.V.; Bonaviri, C. Native predators control the population of an invasive crab in no-take marine protected areas. Aquatic Conserv. Mar. Freshw. Ecosyst. 2018, 28, 1229-1237. [CrossRef]

8. Madenjian, C.P.; Stapanian, M.A.; Witzel, L.D.; Einhouse, D.W.; Pothoven, S.A.; Whitford, H.L. Evidence for predatory control of the invasive round goby. Biol. Invasions 2011, 13, 987-1002. [CrossRef]

9. Fricke, R.; Eschmeyer, W.N.; Fong, J.D. Eschmeyer's Catalog of Fishes: Species by Family/Subfamily. California Academy of Sciences, San Francisco, USA. Available online: http://researcharchive.calacademy.org/research/ichthyology/catalog/ SpeciesByFamily.asp (accessed on 17 November 2020).

10. Nelson, J.S.; Grande, T.C.; Wilson, M.V.H. Fishes of the World, 5th ed.; John Wiley and Sons: Hoboken, NJ, USA, $2016 ;$ p. 752.

11. Kovačić, M. Checklist of gobies (Teleostei: Gobiidae) of the Mediterranean Sea and a key for species identification. Zootaxa 2020, 4877, 75-101. [CrossRef]

12. Hajji, F.; Ouannes-Ghorbel, A.; Ghorbel, M.; Jarboui, O. Diet shifts of Gobius paganellus (Teleostei, Gobiidae) from the Gulf of Gabes (Central Mediterranean). Vie Milieu 2012, 62, 69-76.

13. Hajji, F.; Ouannes-Ghorbel, A.; Ghorbel, M.; Jarboui, O. Reproductive biology of the rock goby, Gobius paganellus (Actinopterygii: Perciformes: Gobiidae), on the southern Tunisian coast (Gulf of Gabes). Cienc. Mar. 2012, 38, 505-515. [CrossRef]

14. Kovačić, M.; la Mesa, A. Feeding ecology of the Buen's goby, Buenia affinis, in the Kvarner area (Adriatic Sea). Vie Milieu 2008, 58, 277-281.

15. Tiralongo, F.; Messina, G.; Lombardo, B.M. First data on habitat preference, diet and length-weight relationship of Gobius incognitus Kovačić \& Šanda, 2016 (Pisces: Gobiidae). Acta Adriat. 2020, 61, 67-78. [CrossRef]

16. Iglésias, S.P.; Vukić, J.; Sellos, D.Y.; Soukupová, T.; Šanda, R. Gobius xoriguer, a new offshore Mediterranean goby (Gobiidae), and phylogenetic relationships within the genus Gobius. Ichthyol. Res. 2021, 1-15. [CrossRef]

17. Kovačić, M.; Šanda, R. A new species of Gobius (Perciformes: Gobiidae) from the Mediterranean Sea and the redescription of Gobius bucchichi. J. Fish Biol. 2016, 88, 1104-1124. [CrossRef]

18. Kovačić, M.; Patzner, R.; Schliewen, U. A first quantitative assessment of the ecology of cryptobenthic fishes in the Mediterranean Sea. Mar. Biol. 2012, 159, 2731-2742. [CrossRef]

19. Miller, P.J. Gobiidae. In Fishes of the North-Eastern Atlantic and Mediterranean; Whitehead, P.J.P., Bauchot, M.L., Hureau, J.C., Nielsen, J., Tortonese, E., Eds.; UNESCO: Paris, France, 1986; pp. 1019-1085.

20. Tortonese, E. Mediterranean fishes present in the Red Sea: Pan-oceanic and anti-lessepsian species. Cybium 1984, 8, 99-102.

21. Engin, S.; Seyhan, K. Biological Characteristics of rock goby, Gobius paganellus (Actinopterygii: Perciformes: Gobiidae), in the South-Eastern Black Sea. Acta Ichthyol. Pisc. 2009, 39, 111-118. [CrossRef]

22. Miller, P.J. Age, growth, and reproduction of the rock goby, Gobius paganellus L., in the Isle of Man. J. Mar. Biol. Assoc. UK 1961, 41, 737-769. [CrossRef]

23. Wilkins, H.K.A.; Myers, A.A. Microhabitat utilisation by an assemblage of temperate Gobiidae (Pisces: Teleostei). Mar. Ecol. Prog. Ser. 1992, 90, 103-112. [CrossRef]

24. Azevedo, J.M.N.; Simas, A.M.V. Age and growth, reproduction and diet of a sublittoral population of the rock goby Gobius paganellus (Teleostei, Gobiidae). Hydrobiologia 2000, 440, 129-135. [CrossRef]

25. Louiz, I.; Attia, M.B.; Hassine, O.K.B. Some aspects of reproductive biology of Gobius paganellus (Gobiidae) on the north-eastern coasts of Tunisia (Bizerta lagoon). J. Mar. Biol. Assoc. UK 2013, 93, 2235-2246. [CrossRef]

26. Mazé, R.A. Seasonal and ontogenetic diet shift in an intertidal population of Gobius paganellus (Teleostei, Gobiidae) from the Cantabrian Coast. Vie Milieu 2004, 54, 1-6.

27. Katsanevakis, S.; Poursanidis, D.; Yokes, M.B.; Mačić, V.; Beqiraj, S.; Kashta, L.; Sghaier, Y.R.; Zakhama-Sraieb, R.; Benamer, I.; Bitar, G.; et al. Twelve years after the first report of the crab Percnon gibbesi (H. Milne Edwards, 1853) in the Mediterranean: Current distribution and invasion rates. J. Biol. Res. 2011, 16, 224-236.

28. Relini, M.; Orsi, L.; Puccio, V.; Azzurro, E. The exotic crab Percnon gibbesi (H. Milne Edwards, 1853) (Decapoda, Grapsidae) in the Central Mediterranean. Sci. Mar. 2000, 64, 337-340. [CrossRef]

29. Suaria, G.; Pierucci, A.; Zanello, P.; Fanelli, E.; Chiesa, S.; Azzurro, E. Percnon gibbesi (H. Milne Edwards, 1853) and Callinectes sapidus (Rathbun, 1896) in the Ligurian Sea: Two additional invasive species detection made in collaboration with local fishermen. BioInvasions Rec. 2017, 6, 147-151. [CrossRef]

30. Pipitone, C.; Badalamenti, F.; Sparrow, A. Contribution to the knowledge of Percnon gibbesi (Decapoda, Grapsidae), an exotic species spreading rapidly in Sicilian waters. Crustaceana 2001, 74, 1009-1017.

31. Sciberras, M.; Schembri, P.J. Biology and interspecific interactions of the alien crab Percnon gibbesi in the Maltese Islands. Mar. Biol. Res. 2008, 4, 321-332. [CrossRef] 
32. Crocetta, F.; Shokouros-Oskarsson, M.; Doumpas, N.; Giovos, I.; Kalogirou, S.; Langeneck, J.; Tanduo, V.; Tiralongo, F.; Virgili, R.; Kleitou, P. Protect the natives to combat the aliens: Could Octopus vulgaris Cuvier, 1797 be a natural agent for the control of the lionfish invasion in the Mediterranean Sea? J. Mar. Sci. Eng. 2021, 9, 308. [CrossRef]

33. Kaldonski, N.; Lagrue, C.; Motreuil, S.; Rigaud, T.; Bollache, L. Habitat segregation mediates predation by the benthic fish Cottus gobio on the exotic amphipod species Gammarus roeseli. Naturwissenschaften 2008, 95, 839-844. [CrossRef]

34. Maljković, A.; van Leeuwen, T.E.; Cove, S.N. Predation on the invasive red lionfish, Pterois volitans (Pisces: Scorpaenidae), by native groupers in the Bahamas. Coral Reefs 2008, 27, 501. [CrossRef]

35. Louette, G. Use of a native predator for the control of an invasive amphibian. Wildl. Res. 2012, 39, 271-278. [CrossRef]

36. Giakoumi, S.; Pey, A.; Thiriet, P.; Francour, P.; Guidetti, P. Patterns of predation on native and invasive alien fish in Mediterranean protected areas. Mar. Environ. Res. 2019, 150, 104792. [CrossRef]

37. Yokes, B.; Galil, B.S. Touchdown-First record of Percnon gibbesi (H. Milne Edwards, 1853) (Crustacea: Decapoda: Grapsidae) from the Levantine coast. Aquat. Invasions 2006, 1, 130-132. [CrossRef]

38. Galil, B.; Froglia, C.; Noel, P.Y. Atlas of Exotic Species in the Mediterranean. 2008. Available online: www.ciesm.org/atlas/ appendix2.html (accessed on 10 December 2020).

39. Deudero, S.; Frau, A.; Cerda, M.; Hampel, H. Distribution and densities of the decapod crab Percnon gibbesi, an invasive Grapsidae, in western Mediterranean waters. Mar. Ecol. Prog. Ser. 2005, 285, 151-156. [CrossRef]

40. Cannicci, S.; Badalamenti, F.; Milazzo, M.; Gomei, M.; Baccarella, A.; Vannini, M. Unveiling the secrets of a successful invader: Preliminary data on the biology and the ecology of the crab Percnon gibbesi (H. Milne Edwards, 1853). Rapp. Com. Int. Mer Médit. 2004, 37, 326.

41. Jones, R.E.; Petrell, R.J.; Pauly, D. Using modified length-weight relationships to assess the condition of fish. Aquac. Eng. 1999, 20, 261-276. [CrossRef]

42. Froese, R. Cube law, condition factor and weight-length relationships: History, meta-analysis and recommendations. J. Appl. Ichthyol. 2006, 22, 241-253. [CrossRef]

43. Riedl, R. Fauna e Flora del Mediterraneo; Franco Muzzio Editore: Padua, Italy, 2010; p. 777.

44. Hayward, P.J.; Ryland, J.S. Handbook of the Marine Fauna of North-West Europe; Oxford University Press: Oxford, UK, 1990 ; p. 816.

45. Hyslop, E.J. Stomach content analysis, a review of methods and their application. J. Fish Biol. 1980, 17, 411-429. [CrossRef]

46. Carrassòn, M.; Matallanas, J.; Casadevall, M. Feeding strategies of deep-water morids on the western Mediterranean slope. Deep Sea Res. 1997, 44, 1685-1699. [CrossRef]

47. N'da, K. Regime alimentaire du rouget de roche Mullus surmuletus (Mullidae) dans le nord du golfe de Gascogne. Cybium 1992, 16, 159-168.

48. Krebs, J.C. Ecological Methodology; Harper \& Row: New York, NY, USA, 1989; p. 620.

49. Novakowski, G.C.; Hahn, N.S.; Fugi, R. Diet seasonality and food overlap of the fish assemblage in a pantanal pond. Neotrop. Ichthyol. 2008, 6, 567-576. [CrossRef]

50. Brown, S.C.; Bizzarro, J.J.; Cailliet, G.M.; Ebert, D.A. Breaking with tradition: Redefining measures for diet description with a case study of the Aleutian skate Bathyraja aleutica (Gilbert 1869). Environ. Biol. Fish. 2012, 95, 3-20. [CrossRef]

51. R Core Team. R: A Language and Environment for Statistical Computing. 2018. Available online: http://www.R-project.org (accessed on 10 December 2020).

52. Zander, C.D.; Berg, J. Feeding ecology of littoral gobiid and blennioid fishes of the Banyuls area (Mediterranean Sea) II. Prey selection and size preference. Vie Milieu 1984, 34, 149-157.

53. Cubedo-Verdiell, D.; Oliva-Paterna, F.J.; Torralva, M. Length-weight relationships for 22 fish species of the Mar Menor coastal lagoon (western Mediterranean Sea). J. Appl. Ichthyol. 2006, 22, 293-294. [CrossRef]

54. Giakoumi, S.; Katsanevakis, S.; Albano, P.G.; Azzurro, E.; Cardoso, A.C.; Cebrian, E.; Deidun, A.; Edelist, D.; Francour, P.; Jimenez, C.; et al. Management priorities for marine invasive species. Sci. Total Environ. 2019, 688, 976-982. [CrossRef]

55. Byun, C.; Lee, E.J. Ecological application of biotic resistance to control the invasion of an invasive plant, Ageratina altissima. Ecol. Evol. 2017, 7, 2181-2192. [CrossRef] [PubMed]

56. Mack, R.N.; Simberloff, D.; Lonsdale, W.M.; Evans, H.; Clout, M.; Bazzaz, F.A. Biotic invasions: Causes, epidemiology, global consequences, and control. Ecol. Appl. 2000, 10, 689-710. [CrossRef]

57. Funk, J.L.; Cleland, E.E.; Suding, K.N.; Zavaleta, E.S. Restoration trough reassembly: Plant traits and invasion resistance. Trends Ecol. Evol. 2008, 23, 695-703. [CrossRef]

58. Elton, C.S. The Ecology of Invasions by Animals and Plants; The University of Chicago Press: Chicago, IL, USA, 1958. 